\title{
ASSESSMENT PRACTICES IN FOUR YEARS TEACHER EDUCATION PROGRAMS
}

\author{
Afshan Huma \\ Assistant Professor, \\ Faculty of Education, Allama Iqbal Open University, \\ Islamabad, Pakistan \\ Email: afshan.huma@aiou.edu.pk

\section{Anjum Akhtar} \\ Research Scholar, \\ Faculty of Education, Allama Iqbal Open University, \\ Islamabad, Pakistan \\ Email: akhteranjum@gmail.com
}

\begin{abstract}
It was aimed and claimed during the teacher education curriculum reform in Pakistan 2010, that formative and summative assessment and evaluation will be improvised at teacher education institutions, to meet the quality of teacher education programs. The study at hand was conducted in two provinces of Pakistan to review the assessment practices within new four years teacher education programs offered between 2010 2018 in two provinces -Punjab and Khyber Pakhtunkhwa. Teachers, students and heads of the institutions were included in the sample of study. Mixed method research design was opted to explore the practices and difference among institutional practices. The findings of the study revealed that Teacher Education Institutions in Punjab practiced more of the modern assessment techniques and yielded better results than Teacher Education Institutions in Khyber Pakhtunkhwa. It was further revealed that Teacher Education Institutions in Private sector practiced formative assessment better than Teacher Education Institutions in the Public sector; while the institutions in public sector were focused more on summative assessment technique. It was concluded that the institutions focusing on modern and formative assessment stemmed into better learning opportunities provided to prospective teachers as compared to the institutions practicing only traditional and summative assessment techniques.
\end{abstract}

\section{KEYWORDS}

Teacher Education, Assessment and Evaluation

\section{INTRODUCTION}

Preamble

Assessment is defined and interpreted differently by the authors and researchers 
according to its applications in various areas of education. Educational assessment can be described as the process of recording, generally in quantifiable expressions i.e. knowledge, skills, attitudes and beliefs in relation to the educational process. In the learning settings it is a process to obtain information, through tests, quizzes, questions, activities or other sources, about the capabilities and achievement of the students. The word assessment is often interchangeably used with testing or evaluation, yet it is different in meaning and implications (Nelson, 2014). The process of classroom teaching basically involves three main phases consisting of aim setting or objectives, providing well-informed learning experience for students that caters for both content and method and the third phase is assessment. Particularly significant feature is that all of the three stages of this process of classroom teaching are overlapping and associated to each other. According to researchers, it is stated that during assessment the teachers mostly focus only on "what" is taught; that is the content or the text book (Humphreys, 2005). This overemphasis by teachers on the content taught produces limitations in the assessment process. Contrary to what Humphreys mentioned, Stiggins (2002) asserted that teachers spend one third to one half of their time on assessment related activities which can go beyond the text books. In addition to this he also describes that assessments in some schools are considered as tests and grading only.

The education system of Pakistan is divided into six levels: Early childhood education, primary schools, middle school, high school, intermediate colleges or higher secondary and university programs, leading to undergraduate, postgraduate and doctorate degrees. Teacher preparation for all these levels is conducted under certain teacher education programs. According to Chang (2014), enormous studies on teacher education in Pakistan are funded by international organizations, which lead to teacher education reforms. The launch of Pre-service Teacher Education (project of USAID) proved to be a milestone in the reform process. It focused on capacity building of prospective teachers and revised curriculum as well as duration of programs. Huma (2013) mentions the salient features of Teacher Education Reforms (TERs). According to which the TER in 2010 marked the commencement of four year TE programs, breaking the model of text books and ensuring semester system in teacher education programs in universities as well as at affiliated colleges thus, replacing the conventional annual examination system. Amongst its many features, one foremost component was the introduction of variety of assessment practices incorporating classroom performance, assignments, presentations, practical work, formative and summative assessment along with portfolios and reflection journals. The study at hand focused on the assessment practices in the four year teacher education programs.

\section{LITERATURE REVIEW}

The quality educational and assessment system is build up through a process of teaching and learning which eventually affects the socio economic growth of the state. 
This is an important aspect which cannot be ignored in order to progress towards the prosperity of the country. The Public and Private sectors of TEIs employed the assessment techniques and strategies to assess memory skills of students instead of affective psychomotor domains. Teachers have lack of proper training causing them to do injustice to their assessment and evaluation of results but to test only the information given on answer scripts. It also lead to ignore the personality characteristics of a student. The examination and evaluation system revolves around the result and marks instead of their learning and knowledge. The examination system also help to assess the teacher's performance but the current examination system of the country also lacks such measuring techniques (Shirazi, 2004). Teacher trainings should also be encouraged and assessed through the same process as of student's assessment by introducing a system of incentives and disincentives (UNESCO, 2005).

In a study conducted by Catlin and Kalina (2000), forty-five out of forty-six faculty reported that there were completely no negative experiences connected with their use of assessments. The main disadvantage of assessment that turned up in this study was more assessments and less time. Respondents noted the time required for planning, administering, and analyzing assessments. In addition to the time required to administer an assessment, if teachers discover that students did not understand a particular lesson, additional class time may be required to review and clarify concepts. The second disadvantage that faculty reported was dealing with negative feedback. One form that negative feedback can take is criticism of teaching in response to faculty requests for student comments on their satisfaction with teaching and classroom activities. Survey respondents warned that one must be willing to take criticism and you might find out you are not teaching as well as you want. Nevertheless, faculty concluded that the information gained from the assessments was valuable, even when it was surprising or discouraging. As one teacher explained that it is good, because you would never have known it if you had not done it.Although teachers seem to dislike external tests and examinations, a survey conducted by Lissitz and Schafer (2002) reported that most teachers rated themselves "good" or "very good" at interpreting standardized test results. According to Lissitz and Schafer eighty-two percent of the teachers surveyed rated themselves as good or very good at explaining standardized test scores. They do not perceive their own knowledge about testing to be a major problem (Lissitz \& Schafer, 2002 ). This signals a shift in interest, which is as a result of external pressure. Although the teachers rated themselves good and very good at explaining standardized test scores, Brookhart (2002) recommends more instruction at both pre-service and in-service level in order for teachers to build repertoire of methods for high quality classroom assessment and less instruction on standardized tests. Brookhart contends that most measurement courses emphasize standardized tests results, which have no meaning to the students. 
Banta (2008) revealed that, the teachers' perceptions of classroom assessment have influence on their classroom assessment practices. Five of the six teachers perceived assessment as testing, and classroom assessment practices were not clearly embedded in their teaching. Teacher experience and teacher education program did not seem to contribute much to teachers' perceptions of classroom assessment; however, teacher's academic qualification seemed to influence teachers' flexibility to accept new ideas. A study conducted by Tirosh (2000) on prospective teachers concluded that prospective teachers' abilities to analyze the reasoning behind students' responses were very poor. This suggests that novices sometimes fail to make sense of students' work, resulting in failure to understand the children's learning difficulties. Tirosh recommended that teachers in training must be helped to understand the mathematics thought processes of their students. Tirosh goes further to suggest that more effort should be devoted to exploring how prospective teachers' programs could improve teachers' knowledge of children's ways of thinking. Brooks and Brooks (1999) reported that, in many districts throughout America, students spend a good deal of time preparing for standardized tests or statewide examinations.

The assessment system of examination strengthens approaches to teaching that recompense memorization. "The more the reproduction, the better and higher are the scores or marks awarded by the examiners". Consequently, the learners learning outcomes are absolutely overlooked in the current examination system. However, the memorization has been assessed extensively. It can easily be concluded from the above excerpts that the assessment system suffers from multiple deficiencies such as encouraging rote-memorization and lacking to adopt critical or analytical approaches for learner's assessment. The Ministry of Education (2009: 41) declared that in future, student performance shall be based on evaluating competence that requires a given skill set in a specialized area. Also periodic reviews of assessment system should be encouraged frequently. The assessment tools shall be explored in addition to ensure the actual use of Formative assessment approaches combined with the Summative approach of high-stake examinations.

The examination system of Pakistan is considered as at high stakes as they exposed a gate to move further, to the next grade, level, profession and other permanent work. The success in the examination lead to many glorified ways however failure can be a disgrace for life. Since the Pakistan Educational system mainly focus on to pass the exam rather than assessing knowledge of students, so the school system does (Erfan, 2000). Teacher education programs across the country were reformed through a huge intervention after the introduction of Nation Standadrd for Teacher. The reform documents claimed to re-engineer the assessment practices in teacher education programs as well (Huma, 2013). Therefore the current study aimed to investigate and compare the assessment practices of both private and public teacher education 
institutions of KP and Punjab.

\section{RESEARCH OBJECTIVES}

1. To identify the assessment practices of public and private teacher education institutions of Punjab and Khyber Pakhtunkhwa

2. To compare the assessment practices of the public sector teachers education institutions of Punjab and Khyber Pakhtunkhwa

3. To compare the assessment practices of the private sector teachers education institutions of Punjab and Khyber Pakhtunkhwa

\section{RESEARCH METHODOLOGY}

The research design used for the study was sequential mixed methods. Quantitative data analysis followed by qualitative data analysis was used to conduct the study. The population of the study included all the government and private teacher education institutes of the two provinces selected for the study i.e. Punjab and KP. Moreover, teachers of the training institutions, students of education colleges enrolled in undergraduate teacher education programs and principals/heads were a part of the sample. The teachers and students were involved in the study as participants to collect quantitative data through questionnaires while the heads of the institutions were interviewed.

Table 1: $\quad$ Sampling Framework

\begin{tabular}{|c|c|c|c|c|c|}
\hline & Punjab & $\mathbf{K P}$ & \multicolumn{2}{|c|}{ Sample size } & \multirow[b]{2}{*}{ Principal } \\
\hline & & & Students & Teachers & \\
\hline Public & $\begin{array}{l}5 \text { institutions } \\
\text { ( } 2 \text { universities } \\
\text { and } 3 \text { colleges) }\end{array}$ & $\begin{array}{l}5 \text { institutions } \\
\text { ( } 2 \text { universities } \\
\text { and } 3 \text { colleges) }\end{array}$ & $\begin{array}{c}8 \text { from } \\
\text { each } \\
\text { institution } \\
(8 \times 10=80)\end{array}$ & $\begin{array}{c}6 \text { from } \\
\text { each } \\
\text { institution } \\
(6 \times 10=60)\end{array}$ & $\begin{array}{c}1 \text { from each } \\
\text { institutions } \\
(1 \times 10)\end{array}$ \\
\hline Private & $\begin{array}{l}5 \text { institutions } \\
\text { ( } 2 \text { universities } \\
\text { and } 3 \text { colleges) }\end{array}$ & $\begin{array}{c}5 \text { institutions ( } \\
\text { universities and } \\
3 \text { colleges) }\end{array}$ & $\begin{array}{c}8 \text { from } \\
\text { each } \\
\text { institution } \\
(8 \times 10=80)\end{array}$ & $\begin{array}{c}6 \text { from } \\
\text { each } \\
\text { institution } \\
(6 \times 10=60)\end{array}$ & $\begin{array}{c}1 \text { from each } \\
\text { institutions } \\
(1 \times 10)\end{array}$ \\
\hline \multirow[b]{2}{*}{ Total } & 10 & 10 & 160 & 120 & 20 \\
\hline & \multicolumn{2}{|c|}{20 institutions } & \multicolumn{3}{|c|}{300 respondents } \\
\hline
\end{tabular}

There were three kinds of data collection instruments used by the researcher for this study including two different questionnaires and an interview protocol. The questionnaire for teachers named as 'Teacher's Perception of Classroom Assessment 
Practices' (Susuwele-Banda, 2005) was a standardized questionnaire. Quantitative part of the study dealt with the interpretation of the numerical data collected through the questionnaires comprising of 15 items on 5 points Likert scale that identified the differences as well as the factors affecting the difference of the assessment practices. Interview protocol was used for collecting qualitative data from principals and Head of departments.

On the basis of literature review and adapted tools, the practices were listed and reported under the following parameters:

1. Monitoring Students Progress

2. Design of the Lesson (tasks, roles, interaction)

3. Students Reasoning

4. Reflect Attention to Students Experiences and Readiness

5. Time and Structure for Reflection

6. Students Participation

7. Immediate Feedback to Slow Learners

8. Prior Knowledge of Students

9. Appropriate Pace of Lesson

10. Students Concept Developing/Problem Solving

11. Lesson Progress based on Students Responses

12. Main Ideas of the Lesson

13. Slow Learners Identification

This was the initial list of parameters and after converging the observational and questionnaires data the results are shown under slightly different headings. Because the adapted list was only made on the basis of previous studies and literature.

\section{RESULTS AND FINDINGS}

Section I: The results and findings in this section are presented in cumulative form after convergence of data collected from observations and questionnaires:

The big picture shown by descriptive analysis reveals highest to lowest percentage of assessment practices reported and observed in the following table:

\begin{tabular}{lc}
\hline Parameters & Percentage \\
\hline Monitoring Students Progress through assessment & $92 \%$ \\
Design of the Lesson (for assessment) & $89 \%$ \\
Checking Prior Knowledge at the beginning of lesson & $82 \%$ \\
Students Experiences and Readiness & $79 \%$ \\
Instructional strategies for formative assessment & $75 \%$ \\
Students Participation in graded classroom activity & $75 \%$ \\
\hline
\end{tabular}




\begin{tabular}{ll}
\hline Slow Learners identification through assessment & $69 \%$ \\
Immediate Feedback to Slow Learners & $69 \%$ \\
Assessment of Students Reasoning during class & $65 \%$ \\
$\begin{array}{l}\text { Revision of Main Ideas of the Lesson as per student } \\
\text { needs }\end{array}$ & $65 \%$ \\
Students Concept Developing through Problem & \\
Solving & $62 \%$ \\
Pace of Lesson in accordance with achievement & $59 \%$ \\
Time and structure for reflection on results & $58 \%$ \\
Lesson Progress based on Students Responses & $53 \%$ \\
\hline
\end{tabular}

The above table depicts which practices are observed and reported in most of the classrooms in teacher education institutes and which are the least practiced. It is clear that none of the assessment activities found totally absent. Teacher educators try to maintain formative and summative assessment practices as much as possible in the given time frame. Further data analysis shows variations between institutions and provinces.

\section{Assessment practices in universities of Punjab}

It was evident that practices in private universities regarding all assessment practices are greater than the public-sector universities. The use of teachers questioning strategies to enhance the development of students conceptual understanding and problem solving in the lesson were mostly being used. The tabular illustration shows the development of students conceptual understanding and problem solving by teacher questioning strategies was widely practiced in private universities. The data showed that multiple assessment techniques were better practiced in private universities as compared to public universities of Punjab.

\section{Assessment practices in Punjab colleges}

Scores of private colleges was greater than the scores of public sector colleges which showed that multiple assessment technique is widely practiced in private colleges of Punjab as compared to public colleges. Immediate feedback was given to students when they needed directions to proceed, and teacher's encouragement of student's class participation was observed in the form of sharing their ideas and having teacherstudent discussions during the lesson. The descriptive analysis showed that the said trend is practiced more in private colleges of Punjab as compared public colleges of Punjab.

Hypothesis: Assessment strategies of private teacher education institutions of Punjab are better as compared to public institutions of Punjab 


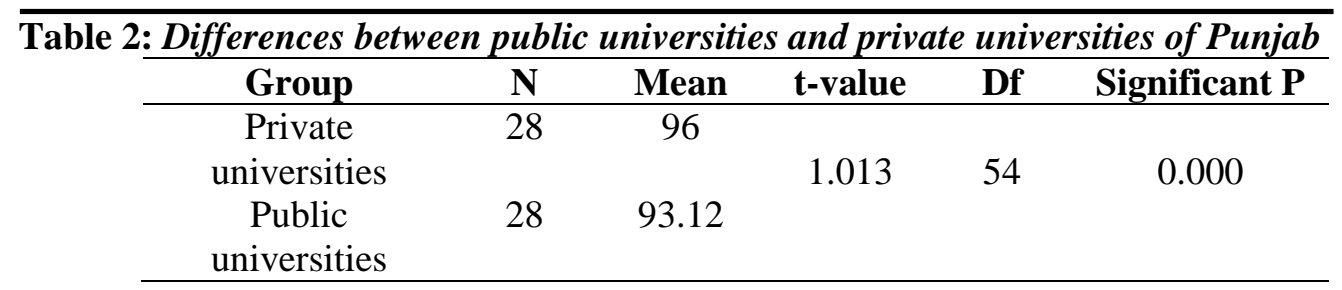

Table 2, depicts that there exists difference between assessment practices of private universities and public universities of Punjab. The t-test results showed that there was statistically significant difference in Punjab as the p-value is less than 0.05. The mean score of private universities was 96 and public universities was 93.12. That is significance difference with $\mathrm{p}$ value 0.00 so the Hypothesis not accepted.

Table 3: $\quad$ Independent Sample t-test calculated to see the differences between public Colleges and private colleges of Punjab

\begin{tabular}{cccccc}
\hline Group & N & Mean & t-value & Df & Significant P \\
\hline $\begin{array}{c}\text { Punjab Private } \\
\text { Colleges }\end{array}$ & 42 & 96.12 & 2.718 & 82 & 0.000 \\
Punjab public colleges & 42 & 90.71 & & & \\
\hline
\end{tabular}

Table 3 depicts that there exists difference between assessment practices of private colleges and public colleges of Punjab. The t-test results showed that there was statistically significant difference in Punjab as the p-value is less than 0.05. The mean score of private colleges was 96.12 and public collage was 90.71 . That is significant difference with $\mathrm{p}$ value 0.00 so the null Hypothesis not accepted.

\section{Assessment practices in universities of KP}

It was evident that practices in private universities regarding all items of check list are greater than the public-sector universities in KP. The tabular illustration and descriptive analysis showed the development of students' conceptual understanding and problem solving by teacher questioning strategies is widely practiced in private universities. It was also evident that multiple assessment techniques were widely practiced in private universities as compared to public universities.

\section{Assessment practices in colleges of KP}

Data showed at the college level immediate feedback was given to students when they needed directions to proceed. Teacher's encouragement of student's class participation by sharing their ideas and having teacher-student discussions in the lesson was observed and reported. The tabular description and descriptive analysis showed that the said trend was practiced more in private colleges of KP as compared public colleges of KP. Scores of private colleges were greater than the scores of public sector colleges. 
Which showed that multiple assessment techniques were widely practiced in private colleges of KP as compared to public colleges

Hypothesis: Assessment strategies of private teacher education institutions of KP are better as compared to public institutions

Table 4: Independent Sample t-test calculated to see the differences between public universities and private universities of $\mathrm{KP}$

\begin{tabular}{llrrrr}
\hline Group & N & Mean & t-value & Df & Significant P \\
\hline $\begin{array}{l}\text { Private } \\
\text { universities }\end{array}$ & 28 & 61.12 & & & \\
$\begin{array}{l}\text { Public } \\
\text { universities }\end{array}$ & 28 & 57.14 & 3.50 & 54 & 0.000 \\
\hline
\end{tabular}

Table 4 depicts that there exists difference between assessment practices of private universities and public universities of KP. The t-test results showed that there was statistically significant difference in Punjab as the p-value is less than 0.05. The mean score of private universities was 61.12 and public universities was 57.14. That is significance difference with $\mathrm{p}$ value 0.00 so the Hypothesis not accepted.

Table 5: Difference between public colleges and private colleges of KP

\begin{tabular}{llllll}
\hline \multicolumn{1}{c}{ Group } & N & Mean & t-value & Df & Significant P \\
\hline $\begin{array}{l}\text { Private Colleges } \\
\text { KP }\end{array}$ & 42 & 69.13 & 9.437 & 82 & 0.005 \\
Public colleges KP & 42 & 62.96 & & & \\
\hline
\end{tabular}

Table 5 depicts that there exists difference between assessment practices of private colleges and public colleges of KP. The t-test results showed that there was statistically significant difference in KP as the p-value is less than 0.05 . The mean score of private colleges was 69.13 and public collage was 62.96 . That is significant difference with $p$ value 0.005 so the null hypothesis is not accepted.

\section{Assessment practices public sector universities of Punjab and KP}

It was evident that practices in public universities of Punjab regarding all items of check list were better than the public-sector universities in KP. The tabular illustration and descriptive analysis showed the development of students' conceptual understanding and problem solving by teacher questioning strategies was better practiced in public universities of Punjab than KP. Scores of public universities of Punjab was better than public universities of KP.

\section{Assessment practices in public colleges of Punjab and public colleges of KP}


The data depicted the consideration of different aspects of assessment such as checking prior knowledge of students by the teachers before delivery of the lesson being taught; immediate feedback given to students when they needed directions to proceed was being practiced by teachers. Teachers' encouragement of student's class participation by sharing their ideas and having teacher-student discussions in the lesson was also observed. The descriptive analysis showed that the said trend was widely practiced in public colleges of Punjab as compared to public colleges of KP. Scores of public colleges of Punjab were better than the scores of public sector colleges of KP that shows that assessment technique is widely practiced in public colleges of Punjab as compared to public colleges of KP.

Hypothesis: Assessment strategies employed by Public teacher education institutions of Punjab are more effective as compared to public teacher education institutions of Khyber Pakhtunkhwa

Table 6: Difference between public teacher education institutions of Punjab and public institutions of $\mathrm{KP}$

\begin{tabular}{cccccc}
\hline Group & N & Mean & t-value & Df & Significant P \\
\hline Public TEI & 70 & 113 & & & \\
Punjab & & & 4.70 & 138 & 0.00 \\
Public TEI & 70 & 109 & & & \\
KP & & & & & \\
\hline
\end{tabular}

In the table $6 \mathrm{t}$-test results showed that there was statistically significant difference between the public teacher education institutions of Punjab and public teacher education institutions of KP as the p-value is less than 0.05. The mean scores of Punjab TEI (113) and KP TEI is (109) shows that the assessment practices of Punjab public TEI were better as compared to the assessment practices of public TEI in KP. Based on $\mathrm{p}$ value, we reject the null hypothesis.

Table 7: Differences between public universities of Punjab and public universities of KP

\begin{tabular}{cccccc}
\hline Group & N & Mean & t-value & Df & Significant P \\
\hline $\begin{array}{c}\text { Public Universities } \\
\text { Punjab }\end{array}$ & 28 & 61.06 & & & \\
$\begin{array}{c}\text { Public Universities } \\
\text { KP }\end{array}$ & 28 & 57.25 & -.796 & 54 & -0.005 \\
\hline
\end{tabular}

Table 7 depicts that there exists difference between assessment practices of public universities of Punjab and public universities of KP. The t-test results showed that there was statistically significant difference in Punjab and KP, as the p-value is less 
than 0.05. The mean score of public universities of Punjab was 61.06 and public universities of KP was 57.25. That is significance difference with $\mathrm{p}$ value -0.005 so the Hypothesis was accepted.

Table 8: Differences between public colleges of Punjab and public colleges of KP

\begin{tabular}{cccccc}
\hline Group & N & Mean & t-value & Df & Significant P \\
\hline $\begin{array}{c}\text { Punjab Public } \\
\text { Colleges }\end{array}$ & 42 & 90.71 & 9.437 & 82 & 0.005 \\
KP public colleges & 42 & 62.96 & & & \\
\hline
\end{tabular}

Table 8 depicts that there exists difference between assessment practices of public colleges of Punjab and public colleges of KP. The t-test results showed that there was statistically significant difference in Punjab and KP as the p-value is less than 0.05. The mean score of public colleges of Punjab was 90.71 and public collage of KP was 62.96. As there is significant difference with $\mathrm{p}$ value 0.00 so the hypothesis is accepted.

\section{Assessment practices of private sector universities of Punjab and KP}

It was observed and reported that practices in private universities of Punjab regarding all items of check list are greater than the private universities in KP. The tabular illustration and descriptive analysis showed the development of students conceptual understanding and problem solving by teacher questioning strategies is widely practiced in public universities of Punjab than KP. Scores of private universities of Punjab were better than private universities of KP.

Assessment practices in private colleges of Punjab and private colleges of KP It was observed that prior knowledge of students is mostly checked by the teachers before delivery of the lesson being taught. Immediate feedback given to students when they needed directions to proceed. Teacher's encouragement of student's class participation by sharing their ideas and having teacher-student discussions in the lesson. The tabular description shows that the said trend is widely practiced in private colleges of Punjab as compared private colleges of KP. Scores of private colleges of Punjab were better than the mean of private sector colleges of KP showing that multiple assessment techniques were practiced in private colleges of Punjab as compared to private colleges of KP.

Hypothesis: Assessment strategies employed by private teacher education institutions of Punjab are more effective as compared to private teacher education institutions of KP

Table 9: Differences between public teacher education institutions of Punjab and public institutions of $\mathrm{KP}$ 


\begin{tabular}{cccccc}
\hline Group & N & Mean & t-value & Df & Significant P \\
\hline $\begin{array}{c}\text { Private TEI } \\
\text { Punjab }\end{array}$ & 70 & 145 & 5.1 & 138 & 0.00 \\
$\begin{array}{c}\text { Private TEI } \\
\text { KP }\end{array}$ & 70 & 123 & - & & \\
\hline
\end{tabular}

In the table 9, t-test results showed that there was statistically significant difference between the private teacher education institutions of Punjab and private teacher education institutions of KP as the p-value is less than 0.05. The mean scores of Punjab TEI (145) and KP TEI is (123) shows that the assessment practices of Punjab private TEI were better as compared to the assessment practices of private TEI in KP. Based on $\mathrm{p}$ value, we accept the hypothesis.

Table 10: Differences between private universities of Punjab and private universities of $\mathrm{KP}$

\begin{tabular}{cccccc}
\hline Group & N & Mean & t-value & Df & Significant P \\
\hline $\begin{array}{c}\text { Private universities } \\
\begin{array}{c}\text { Punjab } \\
\text { Private universities }\end{array}\end{array}$ & 28 & 96.12 & 4.90 & 54 & 0.005 \\
KP & 28 & 91.23 & & & \\
\hline
\end{tabular}

Table 10 depicted that there exists difference between assessment practices of Private universities of Punjab and private universities of KP. The t-test results showed that there was statistically significant difference in Punjab and KP, as the p-value is less than 0.05. The mean score of private universities of Punjab was 96.12 and private universities of KP was 91.23 so the hypothesis is accepted.

Table 11: $\quad$ Differences between public colleges of Punjab and public colleges of KP

\begin{tabular}{cccccc}
\hline Group & N & Mean & t-value & Df & Significant P \\
\hline $\begin{array}{c}\text { Private Colleges } \\
\text { Punjab }\end{array}$ & 42 & 96.71 & 2.17 & 82 & 0.000 \\
$\begin{array}{c}\text { Private colleges } \\
\text { KP }\end{array}$ & 42 & 90.12 & & & \\
\hline
\end{tabular}

Table 11 depicted that there exists difference between assessment practices of public colleges of Punjab and public colleges of KP. The t-test results showed that there was statistically significant difference in Punjab and KP as the p-value is less than 0.05. The mean score of public colleges of Punjab was 96.71 and public collage of KP was 90.12. That is significant difference with $\mathrm{p}$ value 0.00 so the null Hypothesis not accepted. 
Comparative Analysis Teacher education institutions of Punjab and KP Hypothesis : There exists no difference between the assessment strategies of public and private

Table12: Differences between overall teacher education institutions of Punjab and teacher education institutions of $\mathrm{KP}$

\begin{tabular}{cccccc}
\hline Group & N & Mean & t-value & D.f & Significant P \\
\hline $\begin{array}{c}\text { Punjab Teacher } \\
\text { Education }\end{array}$ & 140 & 125 & & & \\
institutions & & & 5.605 & 278 & 0.000 \\
$\begin{array}{c}\text { KP Teacher } \\
\text { Education } \\
\text { institutions }\end{array}$ & 140 & 113 & & & \\
\hline
\end{tabular}

Table 12 depicted the teacher education institutions wise differences between Punjab Teacher Education institutions and KP Teacher Education institutions. The t-test results showed that there was statistically significant difference in Punjab Teacher Education institutions and KP Teacher Education institutions as the p-value is less than 0.05. The mean scores of Punjab TEIs students (125) and KP TEIs students (113) shows that the assessment practices of Punjab Teacher Education institutions were better as compared to the assessment practices of KP Teacher Education institutions however, that difference was significant with $\mathrm{p}$ value 0.000 . The first null hypothesis was not accepted.

\section{Section II}

\section{Prospects and challenges}

In this section, qualitative data was analyzed through thematic analysis. The researcher conducted semi-structured interviews with five head teachers to get their perceptions about assessment practices. Semi-structured interview protocol was developed and validated by the experts. Qualitative analysis start from open coding, then axial coding based on open coding and after analytical and selective coding. This scheme of coding gives us clear picture without losing any word. There are some prospects and challenges as highlighted by the participants about assessment practices.

\section{Formative assessment}

Majority of head teachers had appropriate knowledge about formative assessment, they mentioned that formative assessment plays a vital role in education system. It's an ongoing and helpful procedure. Formative assessment is not only helpful for teachers but it also very helpful for students. This type of assessment is very effective for students and teachers. Mostly teachers mentioned that they use formative assessment 
techniques like activities that easily assesses students' abilities and achievement in classroom.

\section{Summative assessment}

Almost all participants mentioned that summative assessment is also very important part of the assessment practices. In this type, the important decision about students was taken. At the end of the semester this assessment held to decide about students' promotion in the next grade. Teachers who support this assessment practice mentioned that it is very helpful in assessing the overall performance of the student. Summative assessment practices were reported useful by all teachers and head teachers in both provinces equally.

\section{Training and provision of material}

There is a need for proper training in the views of two teachers. They think that they need more training for the implementation of these practices effectively into their classroom. New assessment techniques are activity based so they required different material for the designing of these activates. Training is also important for teachers to follow instructional strategies, because it is difficult to practice without training.

\section{Multiple Assessment Techniques}

Mostly Teachers mentioned different techniques that they used in the classrooms for prospective teachers. So, that they learn in their future, it is mandatory for prospective teachers to learn all these Assessment Techniques for example different activities and assignments of the students in the classroom. All these techniques used as per level of the students and course design. It has to be appropriate to measure students learning. Teachers from both provinces mentioned different techniques that they used in their practice, like assignments, portfolio, quizzes, and different types of tests.

Teachers and students both parties give feedback to each other for the improvement through assessment practices. Teacher gives feedback to the students on weekly basis and in different activities. Teachers collect feedback from students at the end of the course.

In the private TEIs the formative assessment is well practiced as compared to public TEIs. Through qualitative data analysis researcher came to know that the best assessment practices were carried out in Punjab TEIs as compared to the TEIs of KP. Formative assessment was considered as the best practice in Punjab TEIs because they say that it helps them to learn about the nature and hidden talent of the students. Head of the departments further shared that it helps teachers to recognize significance of assessment in the context of portfolio assessment, student-self assessment, peer assessment, criterion referenced assessment, and competency based assessment, NRA 
and their own teaching skills. All these activities were practiced in Punjab, Qualitative data depicts that in both private and public sector of KP TEIs, the formative assessment practice was low than Punjab.

Teachers from Punjab TEIs were aware with the practices of assessment in the classroom. They pay more focus on formative assessment as compare to summative assessment. But in KP TEIs, mostly teachers rely on summative assessment than on formative assessment. Summative assessment is more practiced in the Public TEIs of KP. Punjab TEIs were paying a lot of attention towards the utilization of assessment techniques in the classroom for prospective teachers. Similarly teachers in KP TEIs also consider the utilization of assessment techniques for the better learning of the prospective teachers but less as compare to Punjab. Data predicts that public sector of both provinces Punjab and KP senior teachers didn't want to adapt to the modern assessment practices.

Punjab TEIs provided students with feedback on continuous basis because they considered that feedback is important part for the effective learning of the students. Feedback is not only helpful for students but it also helpful for teachers for the improvement of their teaching. Head Teacher of Private TEIs of Punjab mentioned that she provided Feedback on the reports of students. On the other hand, KP TEIs did not focus on feedback technique.

In both provinces some senior teachers clearly stated that they were not comfortable with the use of new assessment techniques so they did not appreciate or prefer to practice these assessment techniques and strategies. They took all these new assessment practices as a burden. They talked high about paper pencil exam and its effectiveness. They consider old assessment techniques were better as compared to new ones.

In Punjab Principals/Head teachers of TEIs were more qualified and trained as compared to that of KP. Punjab Head teachers supported practicing all new and innovative assessment techniques in the classroom. But in the semi-structured interviews one Head teacher of KP TEIs mentioned that they need more training regarding how to implement effectively assessment practices in the classroom for the effective and better learning of the prospective teachers. Head teachers in both provinces mentioned time and resources as a hurdle in practicing multiple strategies and techniques.

\section{CONCLUSION}

This study was conducted on a small but representative sample. The issues discussed in this study are mostly from questionnaire, lesson observations and the post 
observation interviews with the teachers and head teachers. The results revealed that the teachers' performance in the classroom varies and depends upon various factors. Although some private universities of Punjab and KP have prescribed assessment policies about these newly established programs yet there are variations reported. Shiekh, Chohan, Jawad and Naseem, (2013) maintained that assessment system has been modified to respond to the requirements of the new programs. In addition to the traditional end-of-the-year examinations, formative assessment/on-going assessment is also taking place throughout the semester. In both cases, written tests carry most weight. In this context, the alignment of written test with the approaches promoted through curriculum gains prominence. It becomes imperative to probe whether the changes in curricula and instruction of new teacher education programs are well supported by the assessment instruments. Hence, the significance of assessment in the classroom cannot be negated, as it has a vast grasp on each function related to teaching and learning process. It makes the teachers either in private or in public sector aware of their potential regarding their profession and gives knowledge to students about their academic performance. Moreover, it also provides reasoning to the parents to be confident with their decision of choosing a certain institution for their kids. Most importantly, classroom assessment offers an idea to the administration about the performance and abilities of the selected staff at the institution (Shiekh, Chohan, Jawad \& Naseem, 2013).

There can be many factors affecting classroom practices which were not studied in this research like teachers' knowledge and qualification, experience and skills, large class size, learning and teaching resources, inequitable distribution of resources and ill preparation of teachers, etc. A quality instruction is not possible without quality teachers whereas quality teachers are those who adopt different methods and techniques to make their teaching successful and create an environment for students where they can nourish their abilities and succeed academically. Teachers who encourage students to share their ideas and develop collaboration skills are more effective than those who prefer to maintain strict discipline in their classes. The findings of this study revealed that Punjab public TEIs and KP private and public TEIs showed low practice of student-teacher interaction and students' class participation. The greatest factor that impacts a teacher's effectiveness may lie in his/her ability to use varying and engaging instructional and assessment strategies to deliver knowledge and skills to the students in their classroom. Assessment is a challenging task and effective assessment requires knowledge of the approaches of assessments and mastery over assessment strategies. Therefore, teachers of Punjab and KP private and public TEIs need to be educated and skilful in the application of assessment. Powerful education tools must be utilized for promoting learning in students. 


\section{RECOMMENDATIONS}

1. On the basis of this study it is recommended that teachers need refresher / professional development for using multiple assessment techniques.

2. Departments of education in Punjab and KP may collect follow up data and arrange workshops specifically for the formative and summative assessment techniques.

\section{REFERENCES}

Banta, T. W. (2008). Trying to clothe the emperor. Assessment update, 20 (2), 3-4, 15-16

Brooks, J., \& Brooks, M. (1999). In search of understanding: The case for constructivist classrooms. Alexandria, VA: Association for Supervision and Curriculum Development.

Catlin, A., and Kalina, M.(2000). What Is the Effect of the Cross/Angelo Model of Classroom Assessment on Student Outcome? A Study of the Classroom Assessment Project at Eight California Community Colleges. Research project funded by the California Community College Chancellor's Office, Funds for Instructional Improvement Grant 92-0016.

Chang, F.H. (2014) Globalizing Teacher Education in Pakistan: Its Impact on Program Implementation. INTCESS Conference Proceedings. http://www.ocerints.org/intcess14_epublication/papers/106.pdf

Erfan, N. (2000a).Examination in Pakistan: An Overview. Lahore: Curriculum Research and Development Centre

Huma, A. (2013). Interpretive Analysis of New Teacher Education Curriculum Reform Introduced in Pakistan. ProQuest LLC, Ph.D. Dissertation, Michigan State University. https://d.lib.msu.edu/etd/2285/datastream/OBJ/download/Interpretive_analysis_of_n ew_teacher_education_curriculum_reform_introduced_in_Pakistan.pdf

Humphreys, T. (2005). A different kind of teacher. Limerick: Dr. Tony Humphreys.

Lissitz, R. \& Schafer, W.(2002). Assessment in educational reform: Both means and ends. Boston: Allyn and Bacon.

Nelson, A. (2014). "A contribution to the history of assessment: how a conversation simulator redeems Socratic method". Assessment \& Evaluation in Higher Education. 39 (2): 195-204

Shiekh, M.A., Chohan, B.I., Jawad,A., Naseem, M. (2013). A Comparative Study of the Assessment Practices and Proposed Curriculum Objectives in Revised Teacher Education Programs. Bulletin of Education and Research. Vol. 35, No. 2 (Special Issue) pp. 75-89.

Shirazi, M. (2004).Analysis of Examination System at University Level in Pakistan, [unpublished dissertation] Rawalpindi: University of Arid Agriculture.

Stiggins, R.J. (2002). Where is our assessment future and how can we get there from here? In R. W. Lissitz and W.D. Schafer (Eds.). Assessment in educational reform:Both means and ends (112-125). Boston: Allyn and Bacon.

Susuwele, W., \& Wilkins, J. (2002). Mathematics Curriculum Reform and the Rooted Culture of Teaching and Learning. A Research paper presented at the $24^{\text {th }}$ Annual Meeting of 
the North American Chapter of International Group for the Psychology of Mathematics Education. Athens, GA. October 26-29.

Susuwele-Banda, W. J. (2005). Classroom Assessment in Malawi: Teachersâ Perceptions and Practices in Mathematics_(Doctoral dissertation, Virginia Tech).

https://vtechworks.lib.vt.edu/handle/10919/26269

Tirosh, D. (2000). Enhancing prospective teachers' knowledge of children's conceptions: The case of division of fractions, Journal for Research inMathematics Education, 31(1), $5-25$. 